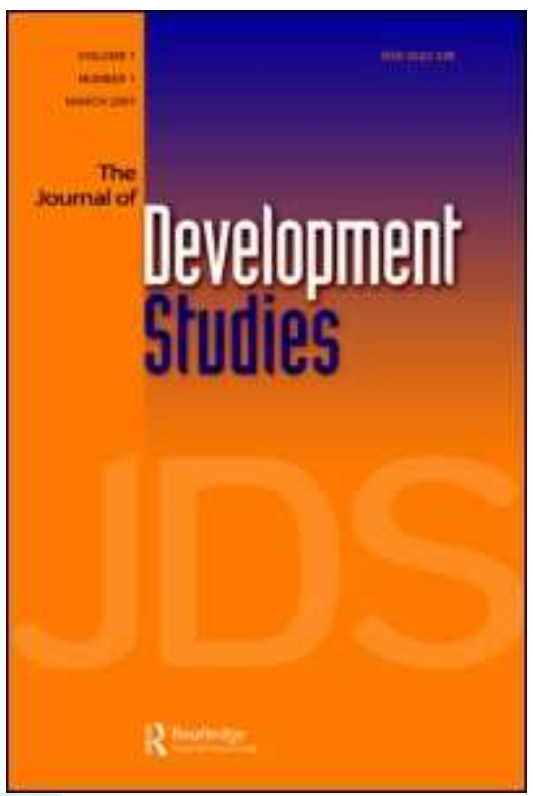

\title{
Smallholder Livelihood Adaptation in the Context of Neoliberal Policy Reforms: A Case of Maize Farmers in Southern Veracruz, Mexico
}

\begin{tabular}{|r|l|}
\hline Journal: & Journal of Development Studies \\
\hline Manuscript ID: & FJDS-2010-Sep-0074.R2 \\
\hline Manuscript Type: & Original Manuscripts \\
\hline Keywords: & $\begin{array}{l}\text { Livelihoods < Economics, Economic development < Economics, } \\
\text { Latin America < Geographical Area, Policy reform < Government, } \\
\text { State Policy, \& Ideologies, Well-being < Health, Agriculture }< \\
\text { Environmental issues }\end{array}$ \\
\hline
\end{tabular}

\section{SCHOLARONE Manuscripts}




\section{INTRODUCTION}

Since the 1980s, the Mexican government has embraced market liberalisation to create substantial gains in efficiency, stimulate economic growth, and reduce rural poverty. In 1986, Mexico joined the General Agreement on Tariffs and Trade (GATT, now the World Trade Organisation) (Bahmani-Oskooee and Hegerty, 2009), and subsequently signed more trade agreements than any other country in the world, the most important being the North American Free Trade Agreement (NAFTA) in 1994 (Henriques and Patel, 2004). Accordingly, Mexico has substantially reformed agricultural policies, and traditional maize farmers have faced difficult economic conditions. Smallholders are forced to adapt to economic pressure from rising imports, low prices for maize and other traditional crops, weak local and regional demands, and large reductions in public sector support for agriculture with far-going consequences for their livelihoods (Wise, 2007).

Seventeen years after the implementation of the NAFTA, the link between liberalised agricultural trade and poverty remains unclear. Although in rural areas, income poverty levels have decreased with about 9 percentage points since 1992, the proportion of the rural population living in poverty remains substantial: 60.8 per cent in 2008 (CONEVAL, 2005). Critics argue that in the short run trade liberalisation puts great stress on certain actors in the economy and that even in the longer run successful open regimes may leave some behind in poverty (Manders et al., 2001; Winters et al., 2002; Anderson, 2005; Eriksen and Silva, 2008). This paper argues that more microlevel knowledge is needed about the adaptation process of different actor groups to get a better understanding why some fare less well during the adjustment process.

During de 1990s, the conviction that openness is good for economic growth was fostered by several cross-country regressions of income per person on international trade (for example, Dollar, 1992; Sachs et al., 1995; Edwards, 1997; Frankel and Romer, 1999). Critical research conducted by Rodríguez and Rodrik (1999) challenges this causation and argues that the conclusions of earlier cross-country studies rest on indicators of openness that are 'poor indicators' of trade barriers or are highly correlated with other sources of bad economic performance. They conclude that there is no clear-cut relationship between integration into the world economy and 
economic growth; rather they argue that this relationship depends on a number of external and country-specific factors.

Studies arguing in favour of the beneficial effects of trade on economic growth often fail to modify the effects for income distribution (Barraud and Calfat, 2008). A noteworthy contribution in this respect is the study of Dollar and Kraay (2001). They conclude that greater openness results in poverty reduction since there is no clear evidence of a correlation between changes in trade and changes in various measures of inequality, such as the Gini coefficient or the Lorenz curve (Dollar and Kraay, 2001). They also found that average income of the poorest quintile moved almost onefor-one with overall average incomes. This means that there is no intrinsic trade-off between long-run aggregate economic growth and overall equality. This result is consistent with the findings of, amongst others, Chen and Ravallion (1997), Bruno et al. (1996), Easterly (1999), and Lundberg and Squire (2000).

However, Ravallion (2001) demonstrates that finding zero average impact on inequality of growth-oriented policy reforms does not mean that the benefits of reforms are generally distributed neutrally. Under the surface of the aggregated outcomes are often losers, even when poverty falls on average. In other words, economic growth measured in national accounts is not always reflected in average household living standards. It is important that the diversities of impacts underlying the averages are not neglected so that governments know what else they have to do to reduce poverty on top of promoting economic growth (Ravallion, 2001:1812). Unfortunately, little is known regarding why some groups of actors are able to take up the opportunities generated by an expanding economy and others are not. Bussolo and Lecomte (1999) argue that a better understanding is necessary on the way specific trade policy changes affect farmers, including whether they have the 'assets' (skills, capital, land, etc) that are likely to allow gains from trade liberalisation, the extent to which they interact with markets, and how vulnerable to change they are.

Going beyond the aggregate level, this paper aims at contributing to a better understanding of the linkages between macro-level trade policies and the social and economic consequences at household or micro-level. We argue that in examining the capacity to respond to economic changes, there is much to learn from the livelihood literature concerning adaptation and coping. In a development context, several studies have demonstrated that rural populations have traditionally coped with crop failure 


\section{CONCEPTUAL FRAMEWORK}

We use the livelihood framework (Chambers, 1989; Chambers and Conway, 1991; Ellis, 2000) to analyse how neoliberal reforms alter the opportunities and constraints of smallholder livelihoods in terms of household adaptation capacity. The concept of livelihood refers to what people do for a living, how they do it, and what they gain by doing it. A commonly used definition is the one provided by Ellis (2000:10), who argues that a livelihood comprises 'the assets (natural, physical, human, financial and social capital), the activities, and the access to these (mediated by institutions and social relations) that together determine the living gained by an individual or household'. The household asset base is shaped by the so-called 'mediating processes' that determine the availability and accessibility of assets and resources in an area. Within the livelihood framework these processes are categorised in, on the one hand, exogenous conditions and trends (or 'vulnerability context'), and on the other hand, policies, institutions, and processes that can be seen as endogenous to social norms 
and structures of which households are permeated (Hoon et al., 1997; Scoones, 1998; Carney, 1999; Ellis, 2000). Following this line of thought, changes in the economic environment are mediating processes that affect the context under which farmers participate in the agricultural sector. Economic changes expose farmers to new conditions to which they will have to adapt. Some farmers may be in the position to take advantage of these changes, while others face increased vulnerability (Eriksen and Silva, 2008). The role of macro-economic policies and institutions as a structural property of local systems is, however, neglected in the majority of livelihood studies, as they most often focus on micro-level complexities in a local context (De Haan, 2000b; Kanji and Barrientos, 2002). Therefore, the significance of an economic shock for rural livelihoods is an underdeveloped topic within the livelihood literature (Ellis, 2000; Dorward et al., 2003). In this paper, we aim to bridge the gap between macrolevel policy changes and micro-level livelihood outcomes.

We use the concept of livelihood strategies for analysing household decisionmaking processes underlying their adaptation to changes related to market liberalisation. A livelihood strategy can be defined as the way households handle opportunities and limitations by adapting the allocation of their resources (Zoomers, 1999:18). The nature, scope, and effectiveness of livelihood strategies depend on a variety of factors including exogenous risks and uncertainties that people have to deal with, the availability of resources at household level, the type and status of these resources, household characteristics, people's capability to create or access them, and the set of goals and priorities defined by the household (Sen, 1984; Moser, 1998; Bebbington, 1999; Zoomers, 1999). Changes related to processes of market liberalisation, by altering these factors, shape the structural contexts, and this may have consequences for people's responses and their ability to reduce the risk in the longer-term and the capability to generate household well-being (Leichenko and O'Brien, 2002).

\section{RECENT MEXICAN AGRICULTURAL REFORMS}

Initial attempts to liberalise the Mexican economy, and in particular, the agricultural sector, started already at the end of the 1980s, but accelerated and became more comprehensive during the 1990s. These changes coincided with negotiations for 
NAFTA, beginning in 1991, and continued well beyond NAFTA's adoption in 1994 (Yúnez-Naude and Taylor, 2006). The reforms of the 1990s intended to stimulate sustainable growth through structural adjustments and economic liberalisation (Nadal, 2000; Wiggins et al., 2002). This 'modernisation' included a mix of monetary, financial, and domestic policies, geared towards market competition through removal of price controls and encouraging more private investments to stimulate production according to the country's 'comparative advantage' (Nadal, 2000).

Financial analysts from international institutions such as the World Bank and OECD predicted that the reforms would create substantial gains in efficiency and would trigger a move away from farming. Yet they also recognised that there would be a distorted distributional impact of agricultural liberalisation and that interventions were needed to protect those who would lose out in the adjustment process (Levy and Van Wijnbergen, 1992, 1994; De Janvry et al., 1995). In particular, negative effects were expected for the rain-fed maize sector (such as lower value of rain-fed land, reduced rents from this asset, and lower demand for rural labour in the maize sector), while sectors such as fruit and vegetable cultivation and the manufacturing industry would flourish (King, 2006:8).

Reforms in the agricultural sector affected both input and product markets. In 1992, a major legal change towards privatisation of the land market was enacted. The main feature of the reform included the amendment of Article 27 of the Mexican Constitution that opened the possibility of defining individual property rights on land. Land that was previously owned under a collective land tenure system - the ejido system - was distributed among the ejidatarios (holders of ejido right), who received official ownership certificates and ever since, can sell the land if they get permission of the ejido assembly (OECD, 2006; Barnes, 2009; Bouquet, 2009). In that same year, the fertiliser industry was liberalised with the privatisation of the fertiliser company FERTIMEX (Nadal, 2000). No longer, the government held domestic fertiliser prices below international prices through budget transfers to FERTIMEX. Additionally, throughout the 1990s, the Mexican government reduced its participation in agriculture by eliminating guaranteed prices to producers of key staples (such as maize and wheat), limiting subsidies to agricultural inputs and the provision of credit and insurance, and reducing participation in the processing of grains, oils, and powdered milk via the National Company for Popular Subsistence, CONASUPO (Compañia 
Nacional de Subsistencias Populares) (Appendini, 2001; Yúnez-Naude and Barceinas Paredes, 2002; Yúnez-Naude, 2003). In 1999, CONASUPO was completely dismantled and the government no longer bought commodities at prices above world prices that they then subsidised and sold to consumers in order to insulate Mexico from international competition (Appendini, 2001; Yúnez-Naude and Barceinas Paredes, 2002; Yúnez-Naude, 2003). Furthermore, the government removed or reduced credit subsidies of the National Rural Credit Bank, BANRURAL (Naylor et al., 2001:5; Rosenzweig, 2003:11). The role of BANRURAL declined and commercial banks were assumed to fill the gap in rural credit provision (King, 2006). Finally, in June 2003, BANRURAL was liquidated due to severe problems in credit recovery and operational efficiency (Rosenzweig, 2003).

Government support that moved away from direct price supports for grains, beans, and oilseeds - administrated through CONASUPO - was redirected to income payments through the Programme for Direct Assistance in Agriculture, PROCAMPO (Programa de Apoyo Directos al Campo) (Yúnez-Naude and Barceinas Paredes, 2002; Taylor et al., 2005; Yúnez-Naude and Taylor, 2006). The main objectives of the programme were to compensate for the anticipated negative income effects of lower crop prices after the implementation of NAFTA and to help farmers to switch to crops that are more competitive in a liberalised context (Nadal, 2000; Sadoulet et al., 2001; Yúnez-Naude and Barceinas Paredes, 2002). Currently, any producer who cultivates a legal crop on eligible land ${ }^{1}$, or uses that land for livestock, forestry production, or some ecological project, can receive PROCAMPO payments, which are made on a per hectare basis. In 2001, a special service - PROCAMPO Capitaliza - was introduced that allowed farmers to receive the remaining years of PROCAMPO, which was supposed to end in 2008 but has been extended to 2012, in one lump sum. These funds would provide farmers with greater capital to invest in agricultural improvements, such as the conversion from maize to cattle-ranching or other crops that adhere more closely to Mexico's comparative advantage (Keleman et al., 2009).

The reforms contributed to a low economic growth at an annual per capital rate of 1.6 per cent between 1992 and 2007 (Zepeda et al., 2009:4). This economic growth has resulted in a gain of about 1.2 million jobs, mostly in the manufacturing and service sector. However, an employment loss in agriculture has more than offset this gain. In total, the employment loss since the early 1990s was more than 2.3 million 


\section{METHODOLOGY AND DATA}

We have studied local adaptation to neoliberal reforms implemented at the beginning of the 1990s through analysing contemporary livelihood strategies at household level and their correlates. Adaptation is a long-term and continuous process that needs at least 10 to 20 years to unfold before significant outcomes and trends are observable (Blanchard, 2000). For this reason, we consider contemporary livelihoods a reliable indicator to measure the outcomes of the adaptation process. In addition, we used qualitative methods to compensate the lack of a quantitative baseline study. These methods allowed us to analyse the livelihood strategies and activities at the time preceding the implementation of most significant policy reforms. A profound literature study on the study area provided additional information on trends and dayto-day life in the recent past.

\subsection{Data collection}

The data used for this study are drawn from a field study conducted by the first author in Morelos, a community in the municipality Soteapan, located on the flanks of a rainforested volcano in the Sierra de Santa Marta biosphere, between March 2007 and May 2010.

The quantitative data on livelihood strategies was collected by means of a household survey among 200 randomly selected households. The survey was addressed towards household heads (representing 848 household members, about 30 per cent of the total population in Morelos). The qualitative data on the types of livelihood strategies and activities used now and at the time preceding the neoliberal policy reforms in the study area was gathered from key informants during participant observation, semi-structured interviews, a focus group discussion, and life-histories with representatives of various groups of community members. Key informant interviews were conducted with 10 farmers aged 30 and above and with 5 representatives of governmental organisations and regional authorities. We organised 
a focus group discussion, as group members have an overlapping spread of knowledge, which may cover a wider field than any single person. For this discussion, we invited 8 farmers representing different key families of the village. The topics addressed in the semi-structured interviews and focus group meetings were predetermined, had a retrospective character, and included, amongst others, history of the village, agricultural developments, changes in markets, crop choices, technical changes, changes in level of wellbeing, and economic development. The life-history method is an open interview technique that concerns the totality of an individual's life as seen within the broader framework in which he or she lives. This research method made it possible to understand the impact of the economic changes in a retrospective way. Life-histories were used to gain insights into socio-economic changes during the last 30 years, which made it possible to relate market liberalisation processes to other changes at both community and household level. In total 4 men and 4 women of 30 years and older were interviewed and asked to tell their life-histories.

\subsection{Defining livelihood strategies and wellbeing}

Contrary to many livelihood studies that classify livelihood strategies on realised income, we qualified contemporary livelihood strategies based on the main productive assets of rural households: land and labour (cf. Jansen et al., 2006). We classify livelihood strategies in terms of assets allocation across distinct activities as it reflects the (strategic) choices of the households to generate household income flows and well-being, while the income composition is also affected by random shocks. We distinguished household time allocated to different types of productive activities (farm self-employment, farm labour employment, non-farm wage-employment, non-farm self-employment, and unskilled domestic labour) and the household land-use pattern (land allocation to maize production, other crops, and pasture).

We used a Ward's linkage hierarchical cluster analysis to agglomerate clusters of observation within our data set (Lattin et al., 2003). Based on statistical results and common sense checks of the resulting groupings, we identified three distinct strategy clusters in the data. This result and the cluster means are used as input for the $k$-means cluster analysis that is used to assign each household to a distinct group or in our case livelihood strategy. 
We analysed the determinants of household choice between livelihood strategies using multinomial logistic regression. Multinomial logistic regression predicts the probability that a household will select each of a set of alternative strategies compared to a reference strategy. We used the traditionally dominant strategy of maize farming as the reference and thus analyse the characteristics of the households that have adjusted to the new situation and revert to an alternative strategy. A positive estimated coefficient indicates an increase in the likelihood that a household chooses the alternative livelihood strategy; a negative coefficient indicates a lower likelihood that a household selects the alternative livelihood strategy.

As we do not have complete income or consumption data, we used the possession of consumer assets as a quantitative indicator for household wellbeing. Following Filmer and Pritchett (2001), we have used the Principal Component Analysis (PCA) to detect one or more underlying factors that are responsible for the co-variation between variables. In this context the factor "wellbeing' is assumed to be underlying the ownership of all the included assets (Clarke, 2006:6). We used the PCA method to compose an Asset Index for comparisons of wellbeing across households. To ensure the sampling adequacy the Kaiser-Meyer-Olkin (KMO) test was used for comparing the magnitudes of observed correlation coefficients with the magnitudes of partial correlation coefficients. The Kaiser-Meyer-Oklin (KMO) measure of sampling adequacy is equal to 0.68 , indicating that the assets share a common factor (Sahn and Stifel, 2003).

\section{LOCAL CONTEXT: NEOLIBERAL OPPORTUNITIES AND CONSTRAINTS}

\subsection{The study area}

The people of Morelos are indigenous Popoluca, for whom Spanish is a second language. The municipality Soteapan is one of the most deprived regions in the state of Veracruz and among the most marginal in the nation. In 2005, about 75 per cent of the population of the municipality lived in extreme poverty and below the food-based poverty line, with incomes of less than US\$51.60 per month (Buckles and Erenstein, 1996; CONEVAL, 2005).

Agriculture is the main economic activity and the key source of income for households in Soteapan. Traditionally, farmers used the milpa system, an 
intercropping system of maize, beans, and squash that is managed through slash and burn with fallow periods and the use of mulch (Blanco Rosas, 2006). Nowadays, the study area is primarily a maize-producing area. In terms of maize production, it belongs to the top five municipalities of a total of 212 municipalities in Veracruz (INEGI, 2005:955-979). Maize production takes place under rain-fed conditions and is entirely manual, due in part to the steep, rocky terrain. The maize farming system is based on both subsistence and commercial production through which farmers interact with (local) maize markets.

Apart from maize, other important agricultural products cultivated in the region are black beans, sugar cane, coffee, pineapple, mango, and papaya. . Since the second half of the 1980s - stimulated by government programmes and rising export of meat to the United States - an increasing number of smallholders have become engaged in cattle breeding in Morelos. According to informants, smallholders consider cattle a more lucrative activity, as maize prices are low.

\subsection{Local effects of neoliberal reforms}

In Morelos, the liberalisation of trade in combination with the privatisation of the markets for land, fertilisers, and credit affected competiveness, relative (input) prices, and farm practices. The land reforms made legal sale and rental of land possible and allowed smallholders to extend the amount of land they own and benefit from economies of scale. Alternatively, individual land property rights allow smallholders to sell their land, exit agriculture, and migrate to urban areas to look for a better paid job. Since the privatisation of the credit market, despachos have arisen: local-level institutions taking advantage of the imperfect credit market by mediating between semi-governmental financial institutions and groups of local smallholders. The new financial intermediaries have made access to credit possible. However, key informants indicated that most smallholders that took loans have ran into debt and did not benefit from the loans in terms of improved productivity. Smallholders indicated that they mainly use the financial support provided by PROCAMPO to buy means of production. Therefore, these subsidies can be seen as an (unintended) opportunity to intensify maize production. Furthermore, PROCAMPO Capitaliza enables smallholders to switch to cattle breeding or start a small business. 
After NAFTA, imported maize caused increased competition in the maize market. This resulted in a dramatic fall of maize prices at local and regional markets. According to Nadal and García Rano (2006), local commercial producers saw their incomes, adjusted for inflation, declining by over 40 per cent between 1993 and 2005 (INEGI, 2005; Nadal and García Rano, 2006). To compensate for the lower maize prices and to boost their income, smallholders use more and expensive fertilisers to increase their production. However, the privatisation of the fertiliser industry caused a dramatic increase in prices for fertilisers and other agrochemical inputs. For example, in 2005 real prices of the Urea and Phosphate Diamónico - commonly used in Morelos - were respectively 191 per cent and 153 per cent higher than the 1990 prices for the average Mexican farmer (SAGARPA, 2002).

During focus group discussions, local smallholders indicated that during the last two decades, significant shifts took place at the local labour market. While in the past people mainly worked at their own parcel, nowadays they can easily find seasonal work at fruit and vegetable plantations in neighbouring villages. Groups of 12 to 15 mostly male villagers travel together to these plantations and stay there for six days. Other types of local employment are working in construction, the cattle industry, or the petroleum industry located in the nearby cities of Minatitlán or Coatzacoalcos. In addition, local smallholders can also (temporary) migrate to the north of Mexico to work in the fruit and vegetable sector or manufacturing industry. According to indepth interviews, an increasing number of young adults leave Morelos temporarily to work off-farm. Our household survey data suggest that only a few households have members who have permanently migrated to the United States or other parts of Mexico. Remarkably, these migrated household members do not contribute significantly to the household budget and therefore remittances are not considered as an important source of income.

Summarising, the changed economic landscape has greatly affected the context in which smallholder farmers operate. These traditional maize farmers faced the privatisation of the land and credit market, lower maize prices, higher prices for agrochemicals, and a shift in employment towards the manufacturing and agricultural export sector. The general hypothesis underlying this study is therefore that the adaptation process of the local smallholders is characterised by less maize production, an increased involvement in alternative agricultural activities (for example, a switch 
towards the cultivation of fruits and vegetables or towards growing pasture in response to the increasing demand for meat) and more off-farm employment in manufacturing and agro-export industries. Due to the large number of changes and the short time in which they were implemented, it is impossible to disentangle the effects of each policy. Therefore, this study focuses on the adaptation process to the total spectrum of changes.

\section{RURAL LIVELIHOODS IN A LIBERALISED ECONOMY}

\subsection{Past livelihood strategies}

Traditionally, people living in the study area cultivated many different food crops (horticulture) at small plots scattered out over the different zones of the Sierra de Santa Marta (Velázquez Hernández, 2001). Maize was the most important crop and source of calorie-intake. Important other plants grown at the plots were squash, chayote, sweet potato, sweet manioc, sugar cane, pineapple, papaya, banana, yam bean, and small unions (Blanco Rosas, 2006). In 1956, Morelos became officially an ejido - a community based organisation in which members, or ejidatarios, held permanent usufruct rights to one or several plots. The implementation of the ejido system affected local livelihood activities as the ejido law forced farmers to cultivate within the borders of the land surface allocated to the ejido. Hence, they became excluded from access to the areas more adequate for producing coffee, hunting, and fishing situated in other parts of the Sierra de Santa Marta. As a result, agriculture transformed from a horticulture system into, what is called, a milpa system during the 1960s and 1970s. This farming system occupied mostly upland areas in southern Mexico and Central America. In the study area, the system was characterized by (i) a central role, both agriculturally and culturally, of maize and beans; (ii) a small size of holdings; and (iii) a high degree of on-farm consumption of production (Dixon et al., 2001). Maize (Zea mays) and kidney beans (Phaseolus vulgaris) became the main crops for subsistence and were used in barter to exchange for pots, lime, salt and other commodities from towns nearby (Foster, 1942).

According to key informants, smallholders substituted monoculture hybrid maize for their traditional milpa system during the 1980s, a process stimulated by government programmes that provided subsidised agrochemicals. Consequently, 
Table 1. Livelihood strategy categories estimated via K-median cluster analysis

\begin{tabular}{|l|r|r|r|}
\hline & Cluster 1 & Cluster 2 & Cluster 3 \\
\hline Land allocation (\% of cultivated land) & & & \\
\hline Maize cultivation & 98.8 & 49.3 & 100.0 \\
\hline Pasture & 1.2 & 50.7 & 0.0 \\
\hline Labour allocation (\% of productive time) & & & \\
\hline Agricultural time on maize & 99.3 & 74.7 & 95.3 \\
\hline Farm self-employment & 97.4 & 74.1 & 39.0 \\
\hline Farm wage employment & 0.7 & 6.1 & 21.6 \\
\hline Non-farm self-employment & 1.4 & 11.8 & 12.2 \\
\hline Non-farm wage employment & 0.5 & 7.9 & 24.2 \\
\hline Domestic time and education (\% of total) & 57.2 & 36.1 & 67.3 \\
\hline Asset Index & -0.31 & 0.56 & 0.68 \\
\hline $\mathrm{n}(\%)$ & $135(67)$ & $31(16)$ & $34(17)$ \\
\hline
\end{tabular}




\begin{tabular}{|l|c|c|c|}
\hline Name livelihood strategy & $\begin{array}{c}\text { Maize } \\
\text { farmer }\end{array}$ & $\begin{array}{c}\text { Cattle and } \\
\text { maize } \\
\text { farmer }\end{array}$ & $\begin{array}{c}\text { Diversified } \\
\text { smallholder }\end{array}$ \\
\hline
\end{tabular}

\section{Strategy 1: Maize farmer}

This livelihood strategy corresponds to the biggest cluster and comprises about 67 per cent of the households in the sample. The most distinguishing feature of households in cluster 1 is that they primarily allocate their household productive time (about 97\%) and land (99\%) to the production of maize. The survey data indicate that smallholders choosing for this type of livelihood strategy have often used the opportunity to apply for financial support of PROCAMPO to intensify their maize production. They have not used the new opportunities created by market liberalisation to supplement their maize income with on-farm and off-farm alternatives, and consequently have the lowest consumptive wealth of the three clusters.

\section{Strategy 2: Cattle and maize farmer}

Cluster 2 includes households that use their agricultural land and labour not only for the production of maize but also for pasture: 50 per cent of land and 25 per cent of agricultural labour. In addition to farm self-employment, these households dedicate 25 per cent of productive time to non-farm and off-farm activities. This cluster represents 16 per cent of the households in the sample and has the second highest Asset Index. Key informants explained that these smallholders have used the opportunity created by the support programmes of the government (such as PROCAMPO Capitaliza) to invest money to start cattle-breeding and so respond to the increasing demand for meat.

\section{Strategy 3: Diversified smallholder}

17 per cent of the households in the sample have diversified their income by engaging in activities outside their farm. The households in this cluster use spend all of their land and about 40 per cent of their productive time for maize production. The remainder of their time they spend mostly in temporary wage-employment at pineapple and sugar cane plantations or in the non-farm sector $(45 \%$ of productive 
Table 2. Reasons for the persistence of maize production as reported by farmers

\begin{tabular}{|l|r|}
\hline Main reason for producing maize & Percentage of farmers \\
\hline I do not know how to growth other crops & 24.5 \\
\hline Maize is basis of local diet/ implies food security & 20.5 \\
\hline Family tradition & 18.5 \\
\hline Other crops have many pests & 12.0 \\
\hline There is no market for other crops & 8.5 \\
\hline Village tradition/Everybody cultivates maize & 6.0 \\
\hline The soil is not adequate for other crops & 7.0 \\
\hline Climate is not adequate for producing other crops & 1.0 \\
\hline Other & 2.0 \\
\hline
\end{tabular}

About a quarter of the smallholders indicated that they do not have adequate knowledge or education to switch to other, more profitable crops. The same number of smallholders continues to produce maize because their own family (18.5\%) and other families in Morelos $(6.0 \%)$ have cultivated maize for many generations. Fathers teach their sons how to produce maize from childhood. Respondents explained as such:

'Producing maize is a family tradition. My father, grandfather, and all my brothers are farmers and all sow primarily maize. Since I was 6 years old, I go together with my father to our parcel and by doing I learned all aspects of the work'.(Ernesto, 28) ${ }^{2}$ 
'Since early childhood I go together with my nephews to the parcel of my grandfather. When we were young, my grandfather teaches us how to produce maize. Today, we help him with the heavy physical work on the land. I am happy that we have learned how to cultivate maize because that is what we eat every day.' (Horacio, 42)

'At school boys do not learn how to provide food for their family. That is what they should know! Here (in Morelos) life is a daily struggle, also for those who have a formal diploma. Look at the sons of the doctor, despite that they both have finished secondary school, they do not have any advantage of being educated, as (non-farm) jobs are hardly present in this area!' (Guadelupe, 41)

In addition, respondents indicated that eating homemade tortillas is part of their culture. For many generations, women make tortillas for their husband and children. This is one of the main daily activities of women, which occupies a major share of their daily time. Making tortillas is a key role of women in household food security, and many times we have heard smallholders phrasing it like 'My wife makes my tortillas. I would starve to death if my wife dies.' (Louis, 32) Eating homemade tortillas is also a source of masculine pride and is linked to farmer identity. A key informant illustrated this as follows:

The people of San Pedro de Soteapan (a neighbouring village) are lazy. They do not produce maize for the market and just live from the money they receive from PROCAMPO. They do not make their own tortillas but buy them in a tortillería (mechanised tortilla shop). Here in Morelos, there are no tortillerías because we are farmers. The tortillas from a tortillería are not filling and my husband would soon be hungry when working in the field. (Francisca, 22)

During informal discussions women declared that homemade tortillas taste better and can be stored longer. Moreover, the fresh maize dough is also an important ingredient in other traditional dishes that are not for sale such as tamales, chamchamitos and potzole $^{3}$. In in-depth interviews, people indicated that another important reason for producing maize is that maize is the key source of calorie-intake while 'other crops do not take off the edge of hunger' (Paco, 25). Producing your own staple is considered safer in terms of food security. Being able to feed oneself is a important drive to produce maize. People do not want to depend on the market and justified the production of maize like this:

'If you sow maize, you have the certainty that you will have something to eat. What if you depend on the market and you have no money to buy tortillas? You will starve to death!' (Liz, 19) 
'In Morelos, people are poor but we always have tortillas to eat. When we have no money, I prepare many tortillas for my children that we eat with salt, tomatoes, or fresh eggs. That gives them energy for the rest of the day. If we did not have our own grains how could I then feed my children?' (Patricia, 33)

'If you produce maize, you have food and do not need money.' (Roberto, 43)

We can conclude that the preference to cultivate maize reflects mainly cultural tradition, a source of identity, the multifaceted role of maize in food security and household reproduction. Remarkable is that more economic reasons such as the limited market for other crops and constraining soil qualities for producing other crops are less frequently mentioned.

\subsection{Household characteristics and adaptation}

In this section, the household variables differentiating adaptation strategy patterns among households are identified. We ran a multinominal logit regression to analyse the relationship between household characteristics and adaptation strategy to get a better understanding of the type of households that are involved in alternative livelihood activities.

Table 3 shows the results of the logistic regressions that examine which variables would affect the probability for households to choose an alternative livelihood strategy other then maize farmer (the reference group). We distinguished human capital (household composition and education level), natural capital (hectares land owned), physical capital (heads of cattle owned) and social capital (membership of a farmer organisation). We do not have good data on financial capital, but assume it is positively correlated with (especially) natural and social capital. Since we dealt with one small sub-location, the households can be assumed to be reasonably homogenous in terms agro-ecological (for example, climate) and physical (for example, access to regional markets) conditions.

Table 3. Household determinants of livelihood strategy choice using mlogit

\begin{tabular}{|l|l|l|l|l|}
\hline Variable & \multicolumn{2}{|l|}{ Diversified smallholder } & \multicolumn{2}{l|}{$\begin{array}{l}\text { Pasture and cattle } \\
\text { farmer }\end{array}$} \\
\hline & Coefficient & St. Error & Coefficient & St. Error \\
\hline
\end{tabular}




\begin{tabular}{|c|c|c|c|c|}
\hline Sex household head $($ female $=1)$ & 2.612 & $0.774 * * *$ & 1.132 & 0.978 \\
\hline Age household head & -0.026 & 0.024 & -0.039 & 0.034 \\
\hline $\begin{array}{l}\text { Education level household head (primary } \\
\text { school completed } 1=\text { yes) }\end{array}$ & 0.4287 & 0.683 & -0.845 & 1.434 \\
\hline Illiteracy household head (yes $=1$ ) & -0.969 & $0.559 *$ & 0.871 & 0.933 \\
\hline Household has no children (yes = 1) & -0.922 & 0.928 & 1.1539 & 1.431 \\
\hline $\begin{array}{l}\text { Household has children under } 5 \text { years old } \\
\text { (yes =1) }\end{array}$ & -0.41 & 0.957 & 0.009 & 1.729 \\
\hline $\begin{array}{l}\text { Household has children } 5 \text { - } 14 \text { years old } \\
(\text { yes = 1) }\end{array}$ & -0.213 & 0.774 & 0.8579 & 1.346 \\
\hline Household size & 0.502 & $0.175 * * *$ & -0.199 & 0.319 \\
\hline Household dependency ratio & -1.526 & $0.622 * *$ & 0.176 & 1.076 \\
\hline Proportion of female household members & 0.168 & 1.176 & -1.468 & 1.841 \\
\hline Land owned (ha.) & 0.059 & 0.04 & 0.218 & $0.059 * * *$ \\
\hline Quality soil $(\operatorname{good}=1)$ & -0.711 & $0.359 * *$ & 0.589 & 0.631 \\
\hline Cattle owned (heads) & 0.147 & 0.093 & 0.554 & $0.122 * *$ \\
\hline Member farmer group & -1.036 & $0.477 * *$ & 1.478 & $0.849 * *$ \\
\hline Constant & 1.179 & 1.676 & -5.901 & $3.315 * *$ \\
\hline $\begin{array}{l}* \text { significant at } 10 \% ; * * \text { significant at } 5 \% \\
\text { Log Likelihood }=-104.870 \\
\mathrm{R}^{2}=0.3810 \\
\text { Prob. Chi }=0 \\
\text { Maize farmer strategy (strategy } 1 \text { ) is the b }\end{array}$ & ** signifi & at $1 \%$ & & \\
\hline
\end{tabular}

Based on the data provided in Table 3, we can conclude that households that have a female household head had a higher likelihood to be engaged in the diversified livelihood strategy. Survey data and key informant interviews indicate that female household headship exists primarily in case a woman becomes a widow. These households look for additional income outside the farm to compensate the loss of the main agricultural producer, especially since agriculture in the area is physically very demanding.

Moreover, households that had an illiterate household head had a lower likelihood to pursue a diversified livelihood strategy than the maize producing strategy. Giving literacy, completing primary school had no significant effect on the probability of engaging in a diverse livelihood. Key informants indicated that people without any education often don't speak Spanish properly, which limits access to information and the possibilities to switch to wage employment, even though the employment itself (at fruit and vegetable plantations and the manufacturing and tourism industry) does not require much education. Uneducated household heads may not be well informed about market prices and benefits of pursuing other activities than 
producing maize, or they just do not have the knowledge and skills to change to alternative crops or to start up their own business. Household survey data on the main reason for producing maize confirm the relevance of access to information, as 24.5 per cent of the smallholders have indicated that they cultivate maize because they do not know how to produce other crops than maize (see Table 2).

Households that are involved in a diversified livelihood strategy have in general relatively large families with many members at working age. This stimulates them to engage in other activities besides farming, as the household members can be involved in different income-generating activities in addition to the production of maize. Households that consider the quality of the soil as good have a lower likelihood to be engaged in the diversified livelihood strategy. Presumably, because household that cultivate land with relatively good soil assume that this should enable them to generate sufficient income to provide in their basic needs and therefore do not switch to additional livelihood activities.

Households that own more land have a higher likelihood to be engaged in the cattle breeding strategy. These households have the security of permanent access to land for fodder and are therefore willing to invest in a stock of cattle. In Morelos, the land rental market is insecure, as it is based on informal agreements (mainly verbal) among villagers. The high risk on arbitrariness and abrupt ending of access discourage smallholders from investing in cattle. Moreover, for smallholders who rent land, income from maize production is hardly profitable and does not allow for high investments such as cattle. Another interesting finding we can extract is that there is a positive association between membership of farmer organisations and pursuing the cattle strategy. This indicates that smallholders use the social network of a farmer organisation to buy and sell their cattle or to obtain market information. By contrast, households that are member of a farmer group are less likely to be engaged in the diversified livelihood strategy. This may be because farmer group members have loans that they use to buy agricultural inputs such as fertilisers and pesticides. Also, diversified farmers may be less interested in joining a farmer group.

\section{DISCUSSION AND CONCLUSIONS}


In the 1990s, the Mexican government signed various free trade agreements and implemented neoliberal policy reforms to stimulate economic growth and alleviate poverty. Due to the introduction of the NAFTA and the neoliberal policy reforms, farmers in the Sierra de Santa Marta in Veracruz no longer operate in a protected, semi-closed market, and their private incomes and livelihoods at the turn of the century were subject to both the opportunities and constraints of international markets. These traditional maize farmers faced the privatisation of the land and credit market, lower maize prices, higher prices for agrochemicals, and a shift in employment towards the manufacturing and agricultural export sector. To adapt to these changes, they could change their focus on maize production to alternative crops such as tomatoes and fruits, livestock, or off-farm employment.

We have assessed to what extent farmers have made these adaptations and who are most likely to adapt and thus benefit from the new opportunities. The outcomes of this study contribute to the limited micro-level knowledge on adaptation processes of local actors to get a better understanding of the decisions that poor people make to specialise or diversify their livelihood activities. Moreover, they show the relation between livelihood strategies and levels of household wellbeing.

We find that local smallholders still primarily cultivate maize in spite of the enormous pressure of maize imports from the United States on the local price. Only 32 per cent of households combine maize farming with cattle breading or off-farm activities. Perhaps local producers need more time to adapt, so it would be interesting to repeat this study in ten years time. Farmers also lack education, which limits their access to the information needed for change. However, the extensive interviews that we held among the local population suggest that at least part of the reason for sticking to maize cultivation against odds is the social significance of maize in Mexican society. The production and consumption of maize are deeply engrained in the nation's social and cultural fabric. In the study area, maize has not only a market value; rather maize symbolises food security, pride, and identity, and employment for family members. The designers of NAFTA failed to take these 'shadow values' into account, leading to their inability to predict widespread refusal to exit maize production. This finding supports the few articles recognising that even though this behaviour is not income-maximizing, it has economic meaning because it reflects the 
social embeddedness of the livelihood adaptation process (Preibisch et al., 2002; Ali, 2005; King, 2007).

Local smallholder farmers seek to overcome the lower maize prices and dropping incomes by intensifying their maize production. Unfortunately, the intensive cultivation of hybrid maize requires the application of high levels of agrochemicals. This trend has had a dramatic impact on the (agro) biodiversity and put pressure on income levels after the abolishment of subsidies on fertilisers and pesticides.

A minority of the smallholder households has diversified their income into other activities than maize farming. A first group engages in off-farm activities, mostly as wage labourers. These households are relatively likely to have female heads and large families with many members in the productive age. This induces them to search employment other than maize cropping. Other households have sufficient land to combine maize farming with cattle production. These are often older farmers who lack the physical strength needed for maize farming. The fact that households with more diversified incomes have higher consumptive wealth and are therefore better off than pure maize farmers, supports the notion of a large intrinsic value of maize production over and above its market price. 


\section{NOTES}

${ }^{1}$ Eligible land is defined as having been cultivated with maize, sorghum, beans, wheat, barley, cotton, safflower, soybeans, or rice in any of the agricultural cycles from fall-winter 1990-91 to spring-summer 1993 (Sadoulet et al., 2001).

${ }^{2}$ All quotes are taken from interviews conducted by the first author between 2007 and 2010. Interview took place in Spanish and all quotes are her translation. Names have been changed to preserve informant anonymity.

${ }^{3}$ Tamales are a traditional Mexican dish made of masa (starchy maize dough), which is steamed or boiled in a leaf wrapper. Chamchamitos are a local type of tamale. Potzole is a Mexican maize drink. 


\section{REFERENCES}

AlI, A. (2005) Livelihood and Food Security in Rural Bangladesh: The Role of Social Capital. Doctoral dissertation, Wageningen University, Wageningen.

Anderson, E. (2005) Openness and Inequality in Developing Countries: A Review of Theory and Recent Evidence. World Development, 33(7), pp.1045-1063.

APPENDINI, K. (2001) De la Milpa a los Tortibonos: La Reestructuración de la Política Alimentaria en México, (Mexico City: El Colegio de Mexico and The United Nations Institute for Social Development).

Bahmani-Oskooee, M. and Hegerty, S. W. (2009) Trade Liberalisation, the Peso, and Mexico's Commodity Trade Flows with the United States. Journal for Development Studies, 45(5), pp.693-725.

BARNES, G. (2009) The Evolution and Resilience of Community-based Land Tenure in Rural Mexico. Land Use Policy, 26(2009), pp.393-400.

Barraud, A. A. and CALfat, G. (2008) Poverty Effects from Trade Liberalisation in Argentina. Journal of Development Studies, 44(3), pp.365-383.

Bebbington, A. (1999) Capital and Capabilities: A Framework for Analyzing Peasant Viability, Rural Livelihoods and Poverty. World Development, 27(12), pp.2021-2044.

Blanchard, O. (2000) Macroeconomics, (New Jersey: Prentice-Hall).

Blanco Rosas, J. L. (2006) Erosion de la Agrodiversidad en la Milpa de los Zoque Popoluca de Soteapan: Xutuchincon y Aktevet. Doctoral dissertation, Universidad Iberoamericana, Mexico City.

BouQueT, E. (2009) State-Led Land Reform and Local Institutional Change: Land Titles, Land Markets and Tenure Security in Mexican Communities. World Development, 37(8), pp.1390-1399.

Bruno, M., Ravallion, M. and SQuiRe, L. (1996) Equity and Growth in Developing Counries: Old and new Perspectives on the Policy Issues. Policy Research Working Paper 1563, World Bank.

Buckles, D. and EREnstein, O. (1996) Intensifying Maize-Based Cropping Systems in the Sierra de Santa Marta, Veracruz. NRG Paper 96-07, CIMMYT.

Bussolo, M. and Lecomte, H. S. (1999) Trade Liberalisation and Poverty. Poverty Briefing Paper No. 6, The Overseas Development Institute.

CARnEY, D. (1999) Approaches to Sustainable Livelihood for the Poor. ODI Poverty Briefings No. 2, The Overseas Development Institute.

Chambers, R. (1989) Editorial Introduction: Vulnerability, Coping and Policy. 20(2), pp.1-7.

Chambers, R. and Conway, G. R. (1991) Sustainable Rural Livelihoods: Practical Concepts for the 21st Century. IDS Discussion Paper No. 296, Institute of Development Studies, University of Sussex.

Chen, S. and Ravallion, M. (1997) What Can New Survey Data Tell Us about Recent Changes in Distribution and Poverty? The World Bank Economic Review, 11(2), pp.357-382. 
Clarke, R. (2006) Measuring Wealth Across Seven Thai Communities. WeD Working Paper No. 17, ESRC Research Group on Wellbeing in Development Countries, University of Bath.

CONEVAL. (2005) Población total, pobreza por ingresos, indicadores, índice y grado de rezago social, según municipio, 2005. Available at: http://www.coneval.gob.mx/mapas/plantillaEdo.jsp?edo=30 [Accessed 8 October 2008].

DAVIES, S. (1993) Are Coping Strategies a Cop Out? IDS Bulletin, 24(4), pp.60-72.

De Bruijn, M. E., Van Dijk, H., KaAg, M. M. A. and Van Til, K. (2005) Sahelian Pathways: Climate and Society in Central and South Mali. Reserach Report 78/2005, African Studies Centre.

De HaAn, L. (2000b) The Question of Development and Environment in Geography in the Area of Globalisation. GeoJournal, 50(2000), pp.359-367.

De JANVRY, A., SAdOUlet, E. and Gordillo DE ANDA, G. (1995) NAFTA and Mexico's Maize Producers. World Development, 23, pp.1349-1362.

DevereuX, S. (1993) Goats before Ploughs: Dilemmas of Household Response Sequencing During Food Shortage. IDS Bulletin, 24(4), pp.52-59.

Dixon, J. M., Gulliver, A. and GiBBon, D. (2001) Farming Systems and Poverty: Improving Farmer's Livelihoods in a Changing World, (Rome, Italy \& Washington DC.: FAO \& World Bank).

Dollar, D. (1992) Outward-oriented Developing Economies Really do Grow More Rapidly: Evidence from 95 LDCs, 1976-1985. Economic Development and Cultural Change, pp.523-544.

Dollar, D. and KraAy, A. (2001) Growth is Good for the Poor. Journal of Economic Growth, 7, pp.195-225.

Dorward, A., Poole, N., Morrison, N., Kydd, J. and Urey, I. (2003) Markets, Institutions and Technology: Missing Links in Livelihood Analysis. Development Policy Review, 21(3), pp.319-332.

EASERLY, S. (1999) Life During Growth. Journal of Economic Growth, 4, pp.239-276.

EDWARDS, S. (1997) Trade Policy, Growth and Income Distribution. American Economic Review, 87(2), pp.205-210.

Ellis, F. (2000) Rural Livelihood and Diversity in Developing Countries: Analysis, Methods, Policy, (Oxford: Oxford University Press).

ERIKSEn, S. and Silva, J. A. (2008) The Vulnerability Context of a Savanna Area in Mozambique: Household Drought Coping Strategies and Responses to Economic Change. Environmental Science \& Policy, 12, pp.33-52.

FILMER, D. and PRITCHETT, L. H. (2001) Estimating Wealth Effects without Expenditure Data-Or Tears: An Application to Educational Enrollments in States of India. Demography, 38(1), pp.115-132.

Foster, G. M. (1942) Indigenous Agriculture Among the Popoluca of Veracruz. American Anthropologist, 44(3), pp.538-542.

Frankel, J. A. and Romer, D. (1999) Does Trade Cause Growth? American Economic Review, 89, pp.379-399. 
Henriques, G. and PATEl, R. (2004) NAFTA, Corn, and Mexico's Agricultural Trade Liberalization. Americas Program Special Report, Interhemispheric Resource Center.

Hoon, P., Singh, N. and Wanmali, S. (1997) Sustainable Livelihoods: Concepts, Principles and Approaches to Indicator Development. Discussion Paper Social Development and Poverty Eradiction, Division, Bureau for Development Policy, United Nations Development Programme.

INEGI (2005) Dirección General de Estadística, Direccción General Adjunta de Estadísticas Sociodemográficas; Direccíon de Análisis y Estudios Demográficos.

Jansen, H. G. P., Pender, J., DAmon, A. and SchiPPER, R. (2006) Rural Development Policies and Sustainable Land Use in the Hillside Areas of Hunduras: A Quantitative Livelihood Approach. Research Report 147, International Food Policy Research Institute

KAnJi, N. and BARrIEntos, S. (2002) Trade Liberalisation, Poverty and Livelihood: Understanding the Linkages: A Review of the Africa Policy and Economics Department for International Development, UK. IDS Working Paper 159, Institute of Development Studies, University of Sussex.

Keleman, A., Hellin, J. and Bellon, M. R. (2009) Maize Diversity, Rural Development Policy, and Farmers' Practices: Lessons from Chiapas, Mexico. The Geographical Journal, 175(1), pp.52-70.

KING, A. (2006) Ten Years with NAFTA: A Review of the Literature and an Analysis of Farmer Responses in Sonora and Veracruz, Mexico. CIMMYT Special Report 06-01, CIMMYT/Congressional Hunger Centre.

KING, A. (2007) Trade and Totomoxtle: Livelihood Strategies in the Totonacan Region of Veracruz, Mexico. Agriculture and Human Values, 24, pp.29-40.

Lattin, J., Douglas Carroll, J. and Green, P. E. (2003) Analyzing Multivariate Data, (Toronto: Thomson Brooks/Cole).

LeICHEnko, R. M. and O'Brien, K. L. (2002) The Dynamics of Rural Vulnerability to Global Change: The Case of Southern Africa. Mitigation and Adaptation Strategies for Global Change, 7, pp.1-18.

LEVy, S. and VAN WiJnBergen, S. (1992) Maize and the Free-Trade Agreement between Mexico and the United States. World Bank Economic Review, 6(3), pp.481-502.

LeVy, S. and VAn Wijnbergen, S. (1994) Mexican Agriculture in the Free Trade Agreement: Transition Problems in Economic Reform. Working Paper No. 36, OECD Development Center.

LundBerg, M. and SQuire, L. (2000) The Simultanoues Evolution of Growth and Inequality. Manuscript, World Bank.

MANDERS, J., BAKER, D. and KorTen, D. (2001) Does Globalization Help the Poor? International Forum on Globalization, 1(3).

Moser, C. O. N. (1998) The Asset Vulnerability Framework: Reassessing Urban Poverty Reduction Strategies. World Development, 26(1), pp.1-19. 
NADAL, A. (2000) The Environmental and Social Impacts of Economic Liberalization on Corn Production in Mexico, (Gland/Oxford: WWF/Oxfam).

Nadal, A. and García Rano, H. (2006) Trade, Poverty \& the Environment: A Case Study in the Biosphere Reserve Sierra de Santa Martha. Final Report to World Wildlife Foundation, World Wildlife Foundation.

Naylor, R. L., Falcon, W. P. and Puente-Gonzalez, A. (2001) Policy Reforms and Mexican Agriculture: Views from the Yaqui Valley. CIMMYT Economics Program Paper No. 01-01, CIMMYT.

OECD. (2006) Policy Brief: Agricultural Policies in Mexico. Policy Note, OECD.

Preibisch, K. L., Rivera Herrejón, G. and Wiggins, S. L. (2002) Defending Food Security in a Free-Market Economy: The Gendered Dimensions of Restructuring in Rural Mexico. Human Organization, 61(1), pp.68-79.

Ravallion, M. (2001) Growth, Inequality and Poverty: Looking beyond Averages. World Development, 29(11), pp.1803-1815.

Rodríguez, F. and RodriK, D. (1999) Trade Policy and Economic Growth: A Sceptic's Guide to the Evidence. Working Paper No. 7081, National Bureau of Economic Research.

RosenzweIg, A. (2003) Changes in Mexican Agricultural Policies, 2001-2003. Comment Presented at the 9th Policy Disputes Information Consortium Workshop, Montreal, April 2003.

SACHS, J. D., WAmer, A., Aslund, A. and Fischer, S. (1995) Economic Reform and the Process of Global Integration. Brookings Paper on Economic Activity, 1995(1), pp.1-118.

Sadoulet, E., De Janvry, A. and Davis, B. (2001) Cash Transfer Programs with Income Multipliers: PROCAMPO in Mexico. World Development, 29(6), pp.1043-1056.

SAGARPA. (2002) Evolución de la Industria Mexicana de Fertilizantes y su Impacto en la Agricultura. Available at: http://www.scribd.com/doc/7637114/EvoluciOn-de-La-Industria-Mexicanade-Fertilizantes [Accessed 08-01-2010].

SAHN, D. and STIFEL, D. (2003) Exploring Alternative Measures of Welfare in the Absent of Expenditure Data. Review of Income and Wealth, 49(4), pp.463-489.

SCOONES, I. (1998) Sustainable Rural Livelihoods: A Framework for Analyse. IDS Working Paper No. 72, Institute of Development Studies, University of Sussex.

SeN, A. (1984) Rights and Capabilities, in: SeN, A. (ed.) Resources, Values and Development. (Oxford: Basil Blackwell), pp.307-324.

SwIFT, J. (1989) Why are Rural People Vulnerable to Famine? IDS Bulletin, 20(2), pp.8-15.

TAylor, J. E., Yúnez-NAude, A., Barceinas Paredes, F. and Dyer, G. (2005) Transition Policy and the Structure of the Agriculture of Mexico, in: HuFF, K. M., Meilke, K., Knuston, R. D., OChOA, R. F., Rude, J. and YúnEZ-Naude, A. (eds.) North American Agrifood Market Integration: Situation and Perspectives. (Altona, Manitoba: Friesen Printers), pp.86-118. 
VelázQueZ HernándeZ, E. (2001) El Territorio de los Popolucas de Soteapan, Veracruz: Transformaciones en la Organización y Apropiación del Espacio. Relaciones, 87(22), pp.17-47.

Wiggins, S., Keilbauch, N., Preibisch, K., Proctor, S., Rivera Herrejón, G. and RodríGuez MuÑOZ, G. (2002) Agricultural Policy Reform and Rural Livelihoods in Central Mexico. Journal of Development Studies, 38(4), pp.179-202.

Winters, L. A., McCulloch, N. and McKay, A. (2002) Trade Liberalisation and Poverty: The Empirical Evidence. CREDIT Research Paper No. 02/22, Centre for Research in Economic Development and International Trade, University of Nottingham.

WiSE, T. A. (2007) Policy Space for Mexican Maize: Protecting Agro-biodiversity by Promoting Rural Livelihoods. Working Paper No. 07-01, Tufts University.

YÚNEZ-NAUDE, A. (2003) The Dismantling of CONASUPO, a Mexican State Trader in Agriculture. World Development, 26(1), pp.97-122.

YÚneZ-NAude, A. and BARCEInAs PAREDES, F. (2002) Lessons From NAFTA: The Case of Mexico's Agricultural Sector. Available at: http://www.globalsubsidies.org/private/modules/knowledgebox/io/file.php?ent

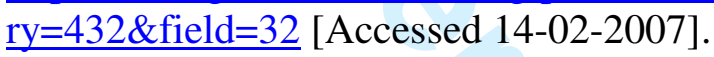

YÚNeZ-NAUde, A. and TAYLOR, J. E. (2006) The Effects of NAFTA and Domestic Reforms in the Agriculture of Mexico: Predictions and Facts. Région et Developpement No.23 [Online]. Available at: http://www.regionetdeveloppement.u-3mrs.fr/pdf/R23/R23_Yunez_Taylor.pdf [Accessed 25-03-2007].

ZePedA, E., Wise, T. A. and Gallagher, K. P. (2009) Rethinking Trade Policy for Development: Lessons from Mexico under NAFTA. Carnegie Endownment for International Peace, Carnegie Endownment for International Peace

ZoOMERS, E. B. (1999) Livelihood Strategies and Development: Experiences from the Bolivian Andes, (Amsterdam: Royal Tropical Institute). 